\title{
Discomfort in E-Learning: Does it Impact Learners?
}

\author{
http://dx.doi.org/10.3991/ijet.v7i2.1717 \\ Issham Ismail, Adi Syahid Mohd Ali and Nizuwan Azman \\ Universiti Sains Malaysia, Penang, Malaysia
}

\begin{abstract}
This study is designed to measure readiness among adult distance learner to embrace new technologies in their studies. This study involved 190 adult distance learner from School of Distance Education, UniversitiSains Malaysia as a respondent and the data were collected by questionnaire that adopted from Parasuraman and Colby (2001) [1]. The study was carried out to see whether adult learners are comfortable to study by using new technology. The result shows that all respondent are comfortable and confidence enough to embrace new technology in their learning. This study also shows that e-learning is one of learning tool that can support adult learning.
\end{abstract}

Index Terms-Adult Learner, Discomfort, Distance Learner,New Technology, Readiness.

\section{INTRODUCTION}

The rapid development of technology opens the door to higher education to further enhance the level of national education. Public universities in Malaysia are aggressively promoting the use of web-based learning or electronic learning (e-learning) for continuous professional development and distance education [2]. Allen and Presnal reported that technology is used in education because it could improve access to education [3]. It reduces cost, increases efficiency, improves quality, provides "on demand" or "just in time" learning, and allows a learner centered approach. If information and communication technologies are used effectively, they could help to create trained, educated and healthy workforces who are capable of building a vibrant and successful economy [4].

Universiti Sains Malaysia (USM) by School of Distance Education has introduced a system of distance education since 1971 and now has full use of the concept e-learning. However, the benefit of an e-learning system will not be maximized unless learners use it[5].Therefore, we can not only see the acceptance of technology to assess the use of e learning in teaching, but students' behavior in the use of technology should also be investigated.

Technology Readiness Index (TRI) was introduced by Parasuraman and Colbyto see the four behaviors in technology readinesses which are the optimism, innovativeness, discomfort and insecurity[1]. According to Parasuraman, a person with optimism and innovativeness and little discomfort and insecurity is more likely to use the technology. Empirical studies suggesting, that people's belief about technology have both positive and negative facets, and can be categorized into four distinct technologies readiness dimension namely the optimism, innovativeness, discomfort and insecurity.

This study therefore is geared to investigate the relationship of one of the indexes of TRI, namely the discom- fort. According to Ming-Ming, discomfort refers to a perceived lack of control over technology and feeling lack of confidence in using the new technologies properly [2]. The discomfort situation always linked with lack of ICT skills among learners. As a result, having to learn new technologies may be a disadvantage or anobstaclein elearning for ICT novices. Therefore, this study focused on discomfort to measure the readiness among adult leaner because they always faced with technical skills in computer used and become frustrated with learning.According to Hamid [6]discomfort situation in e-learning was caused by personal technical skills due to the unconventional elearning environment and isolation from others. Schott et al.[7] mention that the lack of physical interaction also make e-learning student feel isolated and apprehensive.

Much study had been conducted show a limitation of elearning that give a discomfort situation to the learner, example Kearsley[8](2000) and Rumble [9](2000) mention that e-learning comes with benefit such as unlimited access 24 hours, 7 days a week, this privilege does not seem to be feasible for some people in rural areas due to the inability to access Internet services.

A study by Ivergad and Hunt [10] state that poor design of the e-learning courseware is a major issue for learners and e-learning providers. A poor design gave user a feeling of being discomfort and badly treated the system.

According to Lim [11]showed that computer self efficacy is an important factor in adult learners satisfaction and intent to take future e-learning courses.

According to the Economist Intelligence Unit (EIU), Internet penetration rate in Malaysia is estimated at $62 \%$ in 2011, than only $31.8 \%$ in 2004 [12]. Although, there was increases in internet penetration rates, the study of discomfort still significant to see their readiness to use new technology.

This study was conducted based on limitation that always give a discomfort situation to e-learning students. This study focus on adult leaner to measure whether they are comfortable and ready to embrace technology in their distance learning at School of Distance Education at USM.

\section{METHODOLOGY}

The respondent for this study comprise of 190 new undergraduate distance learner from the School of Distance Education, UniversitiSainsMalaysia(USM) for session 2009/2010. Among whom were 85 Bachelor of Science, 21 Bachelor of Arts, 20 Bachelor of Social Sciences and 54 Bachelor of Management Science distance learner. However, out of 190 on papers questionnaire, only 182 returned with complete answers. The questionnaire was 
distributed and collected during new student's registration day.

There are two sections of questionnaire. First section is the demographic questions while second section is discomfort scale adopted by Parasuraman[1]. There are 7 questions for demographic and 5 questions for discomfort scale. Five-point Likert scale is used, with "strongly disagree" (1) and "strongly agree" was (5) to measure the discomfort index. All the data was analyze by statistical software, SPSS 17.0.

\section{RESULTS AND DISCUSSION}

\section{A. Demography}

The result showed that the majority of respondents are aged between 20 to 29 years (72\%) followed by $20.3 \%$ aged between 30-39, 6\% aged 40-49 years and finally $1.6 \%$ aged 50 years. This data shows that most student are exposed to technology, this is because most of them are age between 20-29 years old. The number of women more than men, this is because majority of students in public universities in Malaysia are women. The largest ethnicity is Malay (73.6\%) followed by Chinese and Indian are $(12.6 \%)$ respectively and others (1.6\%). All the respondents do not take a same distance learning courses.

About $44 \%$ from the respondent were from science program, $11 \%$ from art program and 11\% from social science program. The least respondent are from management program which is only $28.6 \%$. From 190 respondents, $71.4 \%$ work at public sector and $24.2 \%$ work at private sector. While self employed and unemployed is $4.4 \%$ respectively. About $22.5 \%$ of the respondents have an income below than RM 1500, 58.2\% between RM 1501 to RM 2500, 14.8 \% between RM 2501 to RM 3500 and only $4.4 \%$ have an income of RM 3501 and above.

\section{B. Descriptive analysis}

Table II shows the question and the statistical analysis for the discomfort index. It is noted that the item has no impact and respondent disagreed to the discomfort situation. These reflect that all respondent are comfortable with new technology and are well adapted to the learning. According to $\mathrm{M}$. Elliot.et al their finding for the six items gives a same result [13].Their study comparesAmerican and Chinese student's readiness and willingness to use innovative technology by assessingtheir technology readiness through the use of the Technology Readiness Index.

Based on the findings the technology system also designs to ordinary people. The result exhibited $45.6 \%$ disagree. Technology used by students is usually already invented for use in ordinary people. Suitability of the students using technology in education is seen some aspect of affordable, internet access and student friendly software. The ability of manufactures producing cheap technology, free internet access and friendly software today to make an ordinary people can also use the technology, especially in learning. Wilhelm et.al said for more than a decade, numerous private and government initiative have assisted poor communities and low resources school to gain computers, educational software and internet [14].As a Lonergansaid IT not only has revolutionalized the way individuals learn and earn a living, but provided a new avenues for communicating and participating in the nation's social and civic life[15].That means everyone will use it without such status for the purposes.
TABLE I.

DEMOGRAPHIC PROFILES

\begin{tabular}{|c|c|c|}
\hline Item & Frequency & Percentage\% \\
\hline \multicolumn{3}{|l|}{ Gender } \\
\hline Male & 74 & 40.7 \\
\hline Female & 108 & 59.3 \\
\hline \multicolumn{3}{|l|}{ tAge(year) } \\
\hline 20 to 29 & 131 & 72.0 \\
\hline 30 to 39 & 37 & 20.3 \\
\hline 40 to 49 & 11 & 6.0 \\
\hline 50 and above & 3 & 1.6 \\
\hline \multicolumn{3}{|l|}{ Ethnic } \\
\hline Malay & 134 & 73.6 \\
\hline Chinese & 37 & 12.1 \\
\hline Indian & 11 & 12.6 \\
\hline Others & 3 & 1.6 \\
\hline \multicolumn{3}{|l|}{ Marital } \\
\hline Single & 97 & 53.3 \\
\hline Married & 81 & 44.5 \\
\hline Single Parent & 3 & 1.6 \\
\hline Others & 1 & 0.5 \\
\hline \multicolumn{3}{|l|}{ Program } \\
\hline B. Science & 80 & 71.4 \\
\hline B.Art & 20 & 11 \\
\hline B.Social Sciences & 20 & 11 \\
\hline B.ManagementSc & 52 & 28.6 \\
\hline Others & 10 & 5.5 \\
\hline \multicolumn{3}{|l|}{ Profession } \\
\hline Public Sector & 130 & 71.4 \\
\hline Private Sector & 44 & 24.2 \\
\hline Self-employed & 6 & 3.3 \\
\hline Not Working & 2 & 1.1 \\
\hline \multicolumn{3}{|c|}{ Monthly Income(RM) } \\
\hline Less than 1500 & 41 & 22.5 \\
\hline 1500 to 2500 & 106 & 58.2 \\
\hline 2501 to 3500 & 27 & 14.8 \\
\hline 3501 and above & 8 & 4.4 \\
\hline
\end{tabular}

TABLE II

DESCRIPTIVE STATISTIC OF DISCOMFORT ITEMS

\begin{tabular}{|l|c|}
\hline \multicolumn{1}{|c|}{ Statement(N=190) } & $\begin{array}{c}\text { Strongly Dis- } \\
\text { agree/Disagree }\end{array}$ \\
\hline $\begin{array}{l}\text { Sometimes, you think that technologies } \\
\text { systems are not designed for use by ordinary } \\
\text { people. }\end{array}$ & $45.6 \%$ \\
\hline $\begin{array}{l}\text { Many new technologies have health or safety } \\
\text { risks that are not discovered until after people } \\
\text { have used them. }\end{array}$ & $71.4 \%$ \\
\hline $\begin{array}{l}\text { Technology always seems to fail at the worst } \\
\text { possible time. }\end{array}$ & $54.4 \%$ \\
\hline $\begin{array}{l}\text { It is embarrassing when you have trouble with } \\
\text { a high-tech gadget while people are watching. }\end{array}$ & $51.1 \%$ \\
\hline $\begin{array}{l}\text { New technology makes it too easy for govern- } \\
\text { ments and organization to spy on people }\end{array}$ & $71.9 \%$ \\
\hline
\end{tabular}


The new technology is usually expected to have a health and safety risks. However, refer to the results of the survey $71.4 \%$ disagree with the statement. However from previous study, there were experienced in physical health risk. This data is closely related to the age of respondents, $92.3 \%$ of the respondent aged below 40 years. Health risk in the use of technology usually happens to middle age. Study from Leena and Rauno shows that middle age sometimes or often had pain, numbness or aches in neck, had aches in the hip and lower back, shoulders, feet, wrists or fingers and in elbows or forearms. Middle-aged women had more pain, numbness or aches in the neck than men [16].The study from Perkiö-Mäkelä et al.mention the middle aged experienced in physical health risk, neck shoulders pain and wrist fingers [17].Beside the age factors that give a positives result for the item is their technology usage. They usually use the technology in rare time to complete their assignments, search information and connect to the lectures. Such usage will not give a risk in health or safety risk to user and it suitable to apply in learning.

The survey shows that, $54.4 \%$ disagree that technology always fail at the worst possible time. This result supported by previous study proves that students in technology rich environment experienced positives effect in their achievement for all major areas. The study conducted by Sivin-Kacahalaabout the effect of technology on learning and achievement in all major subject areas [18].Continuity from that study, nowadays student felt comfortable using technology without doubt of any failure on worst time. Basically, the respondent may ready to use technology because they choose to study with school of distance education which implements technology in their learning. A recent study by Shuell\& Faber indicated that students are generally positive about the use of technology in the class when: its use is perceived as improving student learning, computer skills are perceived as beneficial to futures careers [19].Distance education program at USM is one of the oldest distance learning in Malaysia and innovate from time to time to ensure effective learning.

A total of 51.1\% respondents do not feel ashamed when they have a trouble with a high-tech gadget while people are watching. These results indicated a positives and active attitude in learners' readiness to use e-learning. That means they are very enthusiastic and fun using technology. This is consistent with Abu Hassan which states attitude is important to help ensure the effectiveness and success of a student to learn [20]. It also proves that they have a high level of confidence to use technology in public. According to Ahmad Zaki, the level of trust and confidence can lead a change to the better attitude [21]. Therefore student is not only ready in the physical aspect, but they also ready in their mental and emotional to use technology in their learning.

However only $28.1 \%$ felt new technology makes it too easy for government and organization to spy on people. Nowadays people feel that they have a high level security than before, apart in Malaysia; they have an act to secure the technology user. According to Chunshenget al. security management in e learning could allow students, teachers, or institute-proxies to choose the information (say, course related-proxies to choose the information) that they want to share it, allow users to decide their personal policy for privacy protection with easy-to-use environment [22].Thus, security and trustworthiness is not an issue for learners use a technology especially in education

\section{CONCLUSION}

From this study, we find that USM provide a technology based on learner oriented. This concludes that health and risk are not associated in the use of technology for learning. The findings also revealed that the technology is secured from criminal activities such as spying, spamming, hacking and others. We also find that the technology always under maintenance to make sure the learners did not doubt of any failure on worst time. Finally, the distance learners at USM also show a positive and active attitude to the technology in education.

As a conclusion student feels comfortable with the new technology. It serves as benchmark for the School of Distance Education and UniversitiSains Malaysia on the whole to introduce more technology to support their learning process.One of the new technology in learning is being reviewed today is learning by mobile phone as known as M-Learning.

\section{LIMITATION}

This study shows adult leaner comfortable and ready to embrace technology in their learning. However, this study focuses only five items of discomfort adopted from Technology Readiness Index (TRI). This is because other discomfort items not suitable to discus more about adult learners'discomfort.

This study suggests the discomfort in technology among adult leaner was conducted deeply based on their current technology limitations. It is important to make sure technology using in education become effective learning process especially for distance education leaner.

\section{ACKNOWLEDGMENT}

The authors would like to acknowledge UniversitiSains Malaysia for the support under Short Term Grant.

\section{REFERENCES}

[1] Parasuraman A, Colby CL (2001), Techno-Ready Marketing: How and Why Your Customers Adopt Technology, The Free Press, and New York, NY.

[2] Ming-Ming Lai (2008) .Technology readiness, internet, self efficacy and computing experience of professional accounting students. Campus-wide information system, vol.25.no 1, 2008 http://dx.doi.org/10.1108/10650740810849061

[3] Allen, M., \&Presnal, G. (2000). Critical factors required to successfully implement distance learning programs in small states. In Proceeding of the University of West Indies Small States Conference. Ocho Rios, Jamaica, 101-105.

[4] Sachs, J.D. (2003). Readiness for the networked world: A guide for developing countries. Centre of International Development at Harvard University Retrieved. July. 16, 2004, from http://www.readinessguide.org

[5] Pituch, K. A. and Lee, Y. (2006). The Influence of System Characteristics on E-LearningUse. Computers \& Education, 47(2), pp. 222-244. http://dx.doi.org/10.1016/j.compedu.2004.10.007

[6] Hamid,A.A., (2002), 'e-Learning is it the "e" or the learning that matters', Internet and Higher Education, Vol.4,pp. 311-316. http://dx.doi.org/10.1016/S1096-7516(01)00072-0

[7] Schott, M., Chernish, W., Dooley, K.E., \& Linder, J.R., (2003), 'Innovations in Distance Learning Program Development and Delivery’, Online Journal of Distance Learning Administration, vol.6, no. 2

[8] Kearsley, G., (2000), 'Teaching \& Learning in Cyberspace’,URL: http://home.sprynet.com/ gkearsley/chapts.htm 
PAPER

DISCOMFORT IN E-LEARNING: DOES IT IMPACT LEARNERS

[9] Rumble, G., (2000), 'The Globalisation of Open and Flexible Learning : Considerations for Planners andManagers', Online Journal of Distance Learning Administration, vol.3, no.3, pp. 1-15 http://dx.doi.org/10.1080/026805100115425

[10] Ivergard, T. \& Hunt, B., (2005), 'Towards a learning networked organization: human capital, compatibility and usability in elearning systems', Applied Ergonomics, vol.2005, no.36, pp.157167.

[11] Lim, C. K. (2001). Computer self-efficacy, academic self-concept, and other predicators of satisfaction and future participation of adult distance learners. The American Journal of Distance Education, 15(2), 41-51 http://dx.doi.org/10.1080/08923640109527083

[12] Phang, J.,(2004), 'Impact of ICT innovations: The Islamic Context', The Star In Tech, 8 April., p.18

[13] Kevin M. Elliott, Mark C. Hall and Juan (Gloria) Meng (2008), Student Technology Readiness And Its Impact On Cultural Competency, College Teaching Method and Style Journal

[14] Wilhelm,T,Carmen,D, Reynolds,M.(June,2002). Kids count snapshot,Connecting kids to technology: Challenges and opportunities.Baltimore.MD: Annie E. Casey Foundation

[15] Lonergan, J. M. (2000). Internet access and content for urban schools and communities. (Report No. EDO-UD-00-6). New York: ERIC Clearinghouse on Urban Education. (ERIC Document Reproduction Services No. ED446180).

[16] Leena Korpinenand Rauno Pääkkönen. Self-reported use of ICT (Information and communication technology) uptake in 2002 and discomfort amongst Finns aged 45-66. Applied Ergonomics 42(2010)

[17] Perkiö-Mäkelä M., Hirvonen M., Elo A., Ervasti J., Huuhtanen P., Kandolin I., Kauppinen K., Kauppinen T., Ketola R., Lindström K., Manninen P., Mikkola J., Reijula K., 2006. Work and Health e Interview study. Raport of Tables. Finnish Instituteof Occupational Health, Helsinki,(in Finnish)
[18] Sivin-Kachala, J. (1998). Report on the effectiveness of technology in schools, 1990-1997. Software Publishers Association.

[19] Shuell and Farber, 2001 T.J. Shuell and S.L. Farber, Student perceptions of technology use in college courses, Journal of Educational Computing Research 24 (2001), pp. 119-138. http://dx.doi.org/10.2190/YWPN-H3DP-15LQ-QNK8

[20] Abu Hassan Kassim. Malaysia School Science Curriculum. Teaching Module.UniversityTeknologi Malaysia: Skudai, Johor; 2003

[21] Ahmad Zaki Hj. Abd Latiff (2004). Theory Changein Attitude towards Excellencein Leadership. Journal of Education, 4, 79-85

[22] ChunshengYang1 ,Fuhua Oscar Lin, and Hong Lin(2002). "Policy-based Privacy and Security Management for Collaborative Eeducation Systems”. Proceedings of the 5th IASTED International Multi-ConferenceComputers and Advanced Technology in Education (CATE 2002), Cancun, Mexico.

\section{AUTHORS}

Issham Ismail is with the School of Distance Education, Universiti Sains Malaysia, Minden, Pulau Pinang, 11800 Malaysia (e-mail: issham@usm.my).

Adi Syahid Bin Mohd Ali is a student in the School of Distance Education, Universiti Sains Malaysia, Minden, Pulau Pinang, 11800 Malaysia and currently doing his master in Educational Technology in Universiti Sains Malaysia. (e-mail: adisyahid@gmail.com).

Nizuwan Azman is a Research Officer at Advance Medical and Dental Institute, Universiti Sains Malaysia. (e-mail: nizuwanazman@yahoo.com.au).

This work was supported in part by the UniversitiSains Malaysia under Short Term Grant 304/PJJAUH/6311020. Article received 27 September 2011. Published as resubmitted by the authors 27 May 2012. 